\title{
K SYSTÉMOVÉMU POJETÍ EMPIRICKÉHO SOCIOLOGICKÉHO VÝZKUMU
}

PhDr. JIŘí BURIÁNEK, CSc.

Zabýv at se v rámci sociologie tématy metateoretické (nebo přesněji metametodologické) povahy nepatři zřejmě $\mathrm{k}$ úkolům nejatraktivnějším. $\mathrm{K}$ tomuto názoru alespoň svádí pohled na příručky, zabývající se metodologií empirického sociologického výzkumu, jejichž počet postupně, i když nikterak kvapně narůstá. Prohlédneme-li pozorně nejvýznamnější z nich (vedle Příručky pro sociology nutno uvést práce F. Zicha, V. A. Jadova, A. Hirnera), zjišt'ujeme, že všechny se poctivě, třebaže více či méně podrobně vyrovnávají s problematikou východisek a předpokladů empirického výzkuinu stejně tak, jako se základním metodologickým arzenálem technik sběru a zpracováním dat; co však zůstává takřka stranou pozornosti, je odpověd' na otázku, co je empirický výzkum a jaké předpoklady zajišt'ují úspěšné plnění jeho nezastupitelných funkcí. Je sice pravdou, že v poslední době zaznamenáváme v odborné veřejnosti určitou vlnu zvýšeného zájmu o tyto otázky, to však považujeme spíše za impuls k rozpracování některých specifických problémů.

Hlavní otázku, jíž se chceme věnovat, představuje sama povaha jednoho ze základních heuristických postupů marxistické sociologie - empirického sociologického výzkumu. Hledisko, z něhož hodláme vycházet, bude ovšem užší: jde o postižení těch momentů poznávacího procesu, které lze označit jako systémové. Cílem analýzy není terminologická ekvilibristika, nečiníme si ambice v oblasti definitorické, nejde nám o vytváření normativních modelů výzkumu. Zastáváme názor, že systémové pojetí empirického výzkumu není samoúčelem, ale nutností diktovanou potřebami společenské praxe i potřebami rozvoje vědního oboru. Nikdo nepochybuje o významu sociálních a specificky sociologických faktů, jde o to, aby byla získávána adekvátními způsoby, to znamená především cílevědomě a organizovaně. $Z$ toho ovšem plyne, že empirické zkoumání sociální reality musí být prováděno systematicky, a to nejenom ve smyslu využití systémového přístupu v procesech identifikace a operacionalizace, ale také ve smyslu systémového př́stupu k procesu výzkumu a k jeho ř́zení. 
O tom, že vědecké poznání má systémový charakter, netřeba dnes shánět doklady. Již G. W. F. Hegel tvrdil, že filozofování bez systému nemůže být vědecké, i když jiný citát z jeho díla dokumentuje jednoznačně idealistický ráz jeho východisek: „skutečnou formou, v níž existuje realita, může být pouze její vědecký systém.“') Pro zajímavost uved'me Marxovu trefnou citaci Goethova Fausta: „slovy se lze skvěle přít, slovy lze i systém sestavit““, ${ }^{2}$ ) použitou v jiném kontextu, ale rovněž v boji proti spekulativní metodě. Pro př́iklady je ovšem možno chodit ještě dále: už $\mathrm{v}$ antické vědě vznikly soustavy poznatků, které někdy nazýváme přímo systémy (např. u Aristotela), i když meritorně nepoužívaly systémového př́stupu. Nepřistupovaly totiž $\mathrm{k}$ předmětům svého zkoumání jako k systémům. ${ }^{3}$ )

Otázkami aplikace systémového př́stupu a jeho vztahu k marxistické dialektice se zabývá dnes už téměř nepřehledná literatura. ${ }^{4}$ ) Problematika systémovosti vědeckých poznatků nezaujímá místo nejpřednější, což je logické vzhledem $\mathrm{k}$ tomu, že relativní novost (a bohužel v některých př́ipadech i módnost) tohoto přistupu stimuluje přednostně řešení základních otázek gnoseologických a ontologických v tom smyslu, že se častěji uvažuje o systémovém přistupu ve vědě než $k$ vědě samotné. Sociologie vychází ze systémových charakteristik zkoumaných objektů především při systémové interpretaci samotné společnosti a sociální reality vůbec (viz práce Osipova a Afanasjeva), systémovost při vymezování předmětů zkoumání zdůrazňuje v citované práci V. N. Sadovskij. Právě v jeho analýze vazeb mezi objektem, předmětem a fakty se zakládají předpoklady pro to, abychom vytvářeli takové systémy poznatků, které adekvátním způsobem odrážeji objektivní realitú.

Otázka systémového charakteru procesu empirického výzkumu je přirozeně podřízena zásadnímu řešení problémů uvedených výše. Navazuje nakonec i na úvahy o struktuře marxistické sociologie, o hierarchizaci jednotlivých rovin sociologického poznání. Jistě však nebudeme obviněni z násilného roubování systémových principů na speciální otázky $\mathrm{v}$ duchu jakéhosi systémového univerzalismu, prohlásíme-li, že je v logice věci dotáhnout úvahy o plodnosti (a současně o limitech) systémového přístupu až na úroveň jednotlivých heuristických postupů. I tak zůstává téma dosti široké, nebot' je omezeno jedině tím, že nás zajímají postupy, které se obvykle označují jako empirické. Přitom

1) G. W. F. Hegel: Phänomenologie des Geistes. Leiden 1907, s. 3-4.

$\left.{ }^{2}\right)$ K. Marx, B. Engels: Spisy sv. 19. Praha 1966, s. 408.

$\left.{ }^{3}\right)$ Srovnej V. N. Sadovskij: Metodologické problémy výzkumu objektů, které tvoří systémy. In: Sociologie v SSSR. Praha, Svoboda 1967, s. 49-51.

$\left.{ }^{4}\right)$ Viz např. Dialektika a systémový př́stup. Praha, Svoboda 1979; V. P. Kümin: Principy sistemnosti v teorii i metodologii K. Marksa. Moskva 1976; V. N. Sadovskij: Osnovanija obščej těorii sistem. Moskva 1974; I. V. Blauberg, E. G. Judin: Stanovlenije i suščnost' sistemnogo podchoda. Moskva 1973, ad. 
nás nezajímají jednotlivé metody a techniky, ale proces výzkumu jako celek.

Důvody pro to, abychom hovořili o systémovém charakteru empirického sociologického výzkumu, není třeba vidět pouze v tom, že empirické zkoumání jakožto organická součást sociologie slouži - samozřejmě ve svých produktech - odrazu nejsložitější formy pohybu hmoty, což vyžaduje schopnost odrážet složité jevy, které jsou objektivně systémové. Sociologie zkoumá tyto jevy jako sociální systémy, jež vznikají na základě lidských činností (patří do nich vedle činností samotných i podmínky a produkty těchto činností). Systémovému objektu zkoumání musí proto odpovídat i systémové koncipování předmětu výzkumu. Cílem vědy je však získávání poznatků, faktů, a zde F. Cížek ${ }^{5}$ ) správně upozorňuje na to, že vztah mezi systémem objektu a systémem poznatků nespočívá na jejich mechanickém ztotožnění. Stejně jako definujeme teorii jako systém, mohli bychom stručně říci jako systém explanace, můžeme systémově definovat i metodu a jednotlivé heuristické postupy.

Výzkumná činnost představuje navíc sama o sobě sociální proces, a tudíž momenty činnostního zprostředkování posilují a zvýrazňují systémovost poznávacích kroků. Výzkumné činnosti mají svého nositele - výzkumníka, celý proces se odvíjí od objevení se sociální problémovosti určité situace (tuto okolnost postihl pregnantně především $\mathrm{V}$. A. Jadov), a rovněž jeho „referenční rámec" zahrnující celospolečenské procesy a $\mathrm{v}$ nich vznikající konkrétní požadavky dokresluje jeho složitost, strukturovanost a cílové zaměrení. Některé otázky teorie předmětu výzkumu jsou v poslední době aktualizovány (F. Zich). Analýza vnitřních i vnějších souvislostí empirického sociologického výzkumu má svůj význam a je žádoucí, aby vycházela $\mathrm{z}$ jeho jasné koncepce.

Zpřesňování modelových představ o empirickém sociologickém výzkumu provádíme především proto, abychom usnadnili dodržování určitých zásad a principů. Základní obecné metodologické premisy marxismu se nezřídka střetávají, i když nikoli vyhroceně antagonistickým způsobem, s pragmatikou rutinního empirického šetření. Výsledkem není samozřejmě ignorování nebo dokonce negace těchto principů, ale spíše výběr těch pohodlnějších cest empirického zkoumání - v praxi to znamená preferenci výzkumu verbálního a nikoli reálného chování lidí, smíření se s parciálností nebo dokonce izolovaností jednotlivých šetření, nedoceňování dynamických momentů v rovině empirického zkoumání apod. Není sporu o tom, že tuto vzdálenost - nechceme-li mluvit př́mo o mezeře - mezi metodologickými východisky a realitou výzkumné akce je třeba usilovně zkracovat. A právě zde je podle našeho názoru nanejvýš užitečné využívat znalostí toho, jak proces výzkumu funguje, které faktory (objektivní i subjektivní povahy) v něm působí, jaká je vazba mezi cíli výzku-

$\left.{ }^{5}\right)$ F. Ćížek: Teorie a empirie. Praha 1974, s. 255an. 
mu, jeho metodologickou koncepcí a organizačním rámcem výzkumu. Jde krátce řečeno o to adekvátně využívat všech možností, které empirický výzkum poskytuje, a zkvalitn̆ovat ř́zení samotného procesu výzkumu.

Nedomníváme se však, že zvýšení efektivnosti empirického sociologického výzkumu je podmíněno aplikací jednoho závazného modelu. Samozřejmě jde o dosažení shody v určitých zásadách koncipování výzkumů, o pochopení významu st ra te g i e výzkumné akce. Jinak je třeba důrazně upozornit na skutečnost, že empirické zkoumání sociálních jevů, které se vyznačují složitostí, hromadným charakterem, mnohotvárností, atd., nemůžeme chápat jako něco automatického, algoritmizovatelného, kdy stačí na počátku zformulovat zadání nebo předmět a na konci procesu nás čeká jednoznačné a předem připravené řešení. Ostatně: i když by to výzkumníkům život jistě ulehčilo, je dobře, že tomu tak není.

V tomto kontextu by bylo možno diskutovat řadu zajímavých a dosti závažných problémů; různí se například názory na to, zda v každém výzkumu musí být př́tomna hypotéza ${ }^{6}$ ) (a dále jaké má splňovat předpoklady), jaká pravidla mají dodržovat výzkumy hledačského, objevitelského charakteru. Nejde ovšem o to uznat jedno nebo několik schémat za legitimní, ale hledat způsoby práce, které by jednoznačně napomáhaly realizaci již zmíněných teoreticko-metodologických východisek marxistické sociologie. Jsme přesvědčeni, že zejména ve vztahu $\mathrm{k}$ výzkumu jako celku je možno stanovit některá obecná pravidla. $\mathrm{Za}$ škodlivý považujeme extrém, kdy proces výzkumu charakterizuje živelnost, mechanické řazení jednotlivých etap za sebou, izolované, byt' i velmi kvalifikované řešení jednotlivých metodologických otázek, uvádění proklamací, které nejsou naplněny apod.

Velmi často požadujeme, aby v projektu výzkumu byly obsaženy odpovědi na otázku „Co, kde, proč, jak, případně kdy zkoumat?“. Máme za to, že v odpovědi na ono $\mathrm{jak}$ ? nemůže jít jenom o otázky výběru vhodných technik sběru a zpracování dat, ale o celý způsob řešení problému, o celkovou strategii akce, především pak o zajištění jednoty všech postupů.

\section{SYSTÉMOVÉ CHARAKTERISTIKY EMPIRICKÉHO SOCIOLOGICKEHO VÝZKUMU}

Jednou z ústředních kategorií systémového přístupu je pojem celku. Představa o celostnosti zkoumaného systému je ovšem spojena s aplikací dalších pojmů,

\footnotetext{
$\left.{ }^{6}\right)$ Nechceme zde vyostrovat stanoviska, ani vyslovovat kategorické soudy, faktem je, že existuji koncepce či typologie výzkumů (Řehák), které tuto otázku otevírají. Viz též J. Buriánek: K souvislosti mezi hypotézami a cílem výzkumu. Soc. čas., č. 4/1981.
} 
zejména pak kategorie prostředí, element. Nejde tedy o holistickou hypostázi celku, ale o rozvedení principů dialektického materialismu, ve kterém kategoriím celku a části náleží významné místo. Kategorie celkovosti také ani zdaleka není jediným východiskem systémového přístupu - E. G. Judin uvádí ještě jako klíčové pojmy vztahu (mezi elementy systému), struktury a organizace systému, úrovní a hierarchie, řízení, cílů, seberegulace, fungování a rozvoje systému. ${ }^{7}$ ) Definic systému existuje nepřeberné množství, avšak pro náš případ se hodí jednak ty, které chápou systém jako množinu prvků spojených vzájemnými vztahy, jednak ty, které systém definují z kybernetických hledisek za pomoci kategorií „vstup - výstup“, „,informace“, „ř́zení“. Souhlasíme s J. Zeleným, že tento poslední typ zkoumání patří k nejza jímavějším, ${ }^{8}$ ) a podotýkáme, že na tuto variantu definování systému budeme brát ohled.

Začali jsme charakteristiku empirického sociologického výzkumu u kategorie celku, nebot' pro systémový př́stup je charakteristické více či méně striktní ohraničení předmětu. Empirický výzkum chápeme jako celistvou soustavu činností, jednotlivých rozhodovacích kroků a jednotlivých operací. Tyto jednotlivé elementy (at' jde o sestavení dotazníku nebo praktickou realizaci kvótního výběru) nelze analyzovat samostatně, respektive není možné přistupovat $\mathrm{k}$ řešení těchto elementárních otázek mimo celkový kontext výzkumu. Nepovažujeme za nutné zvlášt' zdůrazňovat, že paralelně s procesem členění výzkumu na elementární operace a rozhodovací akty předpokládáme, že mezi těmito elementy existují vzájemné vztahy a nezanedbatelné vazby. Podobně není bez významu uvažovat o „prostředí“ výzkumu, tedy především o celospolečenském kontextu, v němž zkoumání probíhá. Někdy se nelze ubránit dojmu, že metodologické prríručky pojednávají o výzkumu tak, jakoby probíhal ve vzduchoprázdnu, jakoby bylo možno vypreparovat řešení jednotlivých metodologických otázek.

Význam celostního chápání výzkumu je ovšem posílen tím, že jdè o proces „výroby informace“, přesněji řečeno vyhledávání, získávání a zpracování informace. Nemusíme tedy vycházet jenom $\mathrm{z}$ obecné teze o všeobecném charakteru množinově informační stránky ve vztahu k procesům objẹktivní reality $^{9}$ ) a můžeme náš poznatek specifikovat do té míry, že výzkum jako proces tvorby informace sui generis je současně řízeným - a tedy na množství a kvalitě disponsibilních informací závislým - procesem. Systémový charakter empirického výzkumu ve smyslu naplnění principu celistvosti je tedy třeba prosazovat $\mathrm{z}$ toho důvodu, aby informační procesy související s řizením výzkumu

$\left.{ }^{7}\right)$ E. G. Judin: Sistemnyj podchod i princip dějatělnosti. Moskva, Nauka 1978, s. 135 an.

${ }^{8}$ ) Srovnej. J. Zelený: Dialektika a systémové myšlení. In: Dialektika a systémový přístup. Praha 1979 , s. 33.

$\left.{ }^{9}\right)$ J. Zelený, cit. d., s. 38 . 
zabezpečovaly dostatečnou úroveň řešení problému, tedy požadovanou kvalitu výstupní informace (faktů, sociotechnických doporučení apod.).

I když je velmi obtižné empirický výzkum nějak vymezit $\mathrm{z}$ hlediska hranic systému, nabízí se zde možnost postihnout jeho základní rozměry pomocí kategorií vstup a výstup. $\mathbf{Z}$ informačního hlediska bychom měli výzkum charakterizovat jako proces obohacování informace (samozřejmě $v$ aspektu kvalitativním, z kvantitativního hlediska nelze přehlédnout nezbytnou sice, leč masívní redukci informace). To mimochodem znamená, že do tohoto procesu nějaká informace na počátku prostě $\mathrm{m}$ u s í vstoupit. $Z$ tohoto zřetele je empiristická koncepce výzkumu, kde na počátku není nic než tabula rasa, naivní a neudržitelná.

Základním podnětem $\mathrm{k}$ výzkumu a jeho východiskem je problémová situace. ${ }^{10}$ ) Do procesu výzkumu však vstupuje $v$ podobě objednávky, zadání výzkumného úkolu. Zde máme základní vstupní informaci, která však nezůstává jedinou. Jde totiž o to, že $\mathrm{v}$ následujícím kroku musíme zformulovat koncepci výzkumného úkolu, tedy hlavně určit předmět i objekt zkoumání. V rámci formulace předmětu výzkumu je naprosto nezbytné, aby do procesu výzkumu vstoupily informace teoretické, přičemž zdaleka nejde jenom o to, že zadání nemusí být formulováno sociologicky. Dále ukážeme, že začlenění teoreticko-metodologických informací není jednorázovou záležitostí, třebaže na počátku výzkumu je jejich potřeba samozřejmě největší.

Informační kanál, tj. nikterak jednoduchá spojnice mezi vstupem a výstupem, je reprezentován vlastním procesem výzkumu s jeho jednotlivými etapami a náležitostmi. Pro zadavatele nezrídka tento proces představuje onu známou „černou skříňku“, v níž se cosi složitého děje, z níž však registrujeme pouze výstup a nic než výsledek nás také nemusí zajímat. Pro sociologa je takovýto postoj nepřijatelný, je jenom třeba vidět riziko opačného extrému, kdy hlavní smysl je spatřován v náročných operacích „uvnitř“", aniž by podstatně záleželo na výstupu.

Zdá se, že obtížnější je stanovit hranici, kdy výzkum končí, Formálně lze pochopitelně stanovit charakter výstupu (např. odevzdání závěrečné zprávy), problém je $\mathrm{v}$ tom, že shromážděná fakta nemohou být tak krátkodechá - je zcela reálné počítat $s$ možnostmi sekundární analýzy dat atd. Výstupem jsou obvykle interpretovaná (což implikuje nezbytnost aktualizace teoretických momentů) data, obvykle rozšířená o sociotechnická doporučení. Zde si však položme lat'ku o něco výše: je na čase posilovat váhu doporučení pro praxi tím, že na bázi získaných dat provedeme předpověd' „latentních funkcí“, tedy toho, co se od aplikace doporučení očekává a co se (třeba alternativně) stane,

${ }^{10)}$ Naposled to potvrzuje Príručka pro sociology. Praha, Svoboda 1980, s. 145. 
nebudou-li realizována. Chceme tím naznačit, že k otázce výstupu empirického sociologického výzkumu je nutno přistupovat komplexněji.

Poté, co jsme se pokusili o charakteristiku empirického sociologického výzkumu $\mathrm{z}$ hlediska jeho celostnosti, můžeme přikročit $\mathrm{k}$ úvahám o významu dalších systémových určení. Budeme se zabývat otázkou vnitřní struktury výzkumného procesu.

Empirický výzkum je procesem, jehož podstatu tvoří sled jednotlivých kroků (aktů, rozhodnutí), a to $\mathrm{v}$ určitém - do jisté míry dokonce standardním uspořádání. Tyto kroky jsou cílově orientovány k získání potřebné informace a $\mathrm{k}$ vyřešení výzkumného problému, to však neznamená, že vazby mezi nimi jsou jednosměrné. Postup řešení úkolů výzkumu v čase zakládá hlavní, podle našeho názoru ne však jedinou dimenzi tohoto procesu. $\mathrm{V}$ optickém pohledu tuto časovou osu můžeme nazývat horizontální dimenzí. Zásada, že ve výzkumu musí existovat určitá logika návaznosti jednotlivých kroků a etap řešení, je již běžně rozšiřrena a nepředstavuje tudíž zvlášt' aktuální problém. V členění na fáze a etapy samozřejmě nalézáme u jednotlivých autorů (např. Katriak, Michajlov a d.) rozdíly.

Naopak nelze zcela jednoznačně soudit, že je uspokojivě vyřešena otázka spojení obecně metodologické a gnoseologické problematiky s procedurami, technikami, ale také organizačními předpoklady empirického sociologického výzkumu. $\mathrm{V}$ učebních textech tato problematika zahrnuta je, bývá ovšem pojednávána zvlášt', obvykle před rozborem „vlastního“" procesu výzkumu. Přitom je zřejmé, že řešení těchto obecně metodologických otázek není záležitostí jenom výchozích úvah, nýbrž je organicky spojeno s řešením dílčích otázek prakticky ve všech fázích empirického výzkumu. Takže i když rozčleníme výzkum na jednotlivé časové úseky a vymezíme jejich obsah (stanovíme hlavní úkol, který je třeba $\mathrm{v}$ dané etapě vyřešit), $\mathrm{v}$ každém tomto momentu je třeba reprodukovat určitou hierarchii otázek gnoseologických, metodologických, technických a organizačních. Bylo by zkrátka chybou se domnívat, že při rozhodování $v$ pokročilém stadiu rozpracování výzkumného úkolu, dejme tomu při tvorbě škály, nemusíme evokovat řešení obecně metodologických problémů (např̀ otázku možností kvantifikace $\mathrm{v}$ sociologii). $\mathrm{Z}$ toho důvodu jsme se rozhodli zavést a v metodice výuky aplikovat ${ }^{1 /}$ ) další dimenzi, kterou nazýváme vertikální.

Tvrdíme-li, že s analýzou obecně metodologických a gnoseologických předpokladů musí být spojen nejenom empirický výzkum jako celek, ale i řešení každého dílčího technického problému, pak podle našeho názoru vytváříme účinné předpoklady pro boj s empiricistickými tendencemi v chápání sociolo-

11) Viz Kolektiv autorů: Metody a techniky. sociologického výzkumu I. Praha, SPN 1982. 
gického výzkumu. Vycházíme pochopitelně z myšlenky, že gnoseologická problematika jednotlivých etap a kroků je variabilní, že třeba rozhodnutí o aplikaci sociometrického testu vyžaduje analýzu jiných předpokladů, než interpretace výsledků testování hypotéz pomocí chí-kvadrátu. Nejde nám o to za každou cenu zkomplikovat proces empirického zkoumání vynucováním rozsáhlých metodologických analýz před každým rozhodnutím, chceme se jenom ubránit mechanické a rutinní aplikaci určitých technik v rámci byt' i dobře teoreticko-metodologicky fundovaného výzkumu.

Vertikální dimenze empirického výzkumu je tvořena třemi odlišnými, ovšem těsně propojenými rovinami:

1. problémy gnoseologické a gnoseologicko-metodologické: jde o zásadní rozhodovací kroky, které je třeba realizovat na vysoké úrovni obecnosti, nebot' právě ony z velké části určují výsledný tvar výzkumu;

2. problémy konkrétně metodologické: týkají se realizace metodologických východisek, jde o konkrétní formulaci hypotéz, technik sběru a zpracování dat; 3. problémy organizačně technické: tyto rozhodovací kroky na nejnižší úrovni obecnosti vytvářejí praktické realizační předpoklady, mají ráz činností povýtce organizačních.

Ilustrujme tuto koncepci na príkladu. Aplikace sociometrického testu nespočívá jenom $v$ tom, že zkonstruujeme podle řady pravidel a kritérií sociometrický test (rovina konkrétně metodologická). Musíme zvážit gnoseologická a metodologická východiska, vhodnost tohoto postupu ve vztahu $\mathrm{k}$ předmětu a cílům zkoumání, jeho přednosti a omezení (nemusí jít o explicitní kritiku koncepce J. L. Morena, ${ }^{12}$ ) i když i zde je žádoucí určitá informovanost výzkumníka). Přitom nesmíme zapomenout, že sociometrické šetření předpokládá, že se nám podaří skupinu shromáždit $\mathrm{v}$ kompletní podobě - to je ovšem záležitost organizační, dosti často nanejvýš komplikovaná.

Naši představu o struktuře empirického sociologického výzkumu můžeme vyjádřit pomocí modelu uvedeného na následující straně.

Tento model přirozeně zahrnuje pouze východiska analýzy struktury výzkumu. Na jeho základě je možno zpracovat poměrně rozsáhlé blokové schéma, náčrt konkrétních rozhodovacích kroků. $V$ modelu pro didaktické účely jsme vymezili 86 takových kroků, přičemž každý zahrnuje řadu otázek (na různé úrovni obecnosti). Jde samozrejmě o model orientovaný maximalisticky, který může být podle povahy zkoumaného problému redukován. To ovšem znamená, že strukturu výzkumu nechápeme jako něco absolutního a neměnného, jako

12) Případný zájemce jistě nevynechá studii M. Petruska (Sociometrie, Praha 1969), viz též L. Goldmann: Humanitní vědy a filozofie. Praha, 1967. 
Konkretizace výzkumu v čase (sled jednotlivých kroků)

\begin{tabular}{|c|c|c|c|c|c|c|}
\hline \multicolumn{4}{|c|}{ Płípravná fáze } & \multicolumn{2}{|c|}{ Realizační f. } & \multirow[t]{2}{*}{ Závěrečná f. } \\
\hline $\begin{array}{l}\text { Etapa } \\
\text { obecnĕ } \\
\text { orientační }\end{array}$ & $\begin{array}{l}\text { Etapa } \\
\text { konkreti- } \\
\text { zační }\end{array}$ & $\begin{array}{c}\text { Etapa } \\
\text { ověrovací }\end{array}$ & $\begin{array}{c}\text { Etapa } \\
\text { projektová }\end{array}$ & $\begin{array}{l}\text { Etapa } \\
\text { terenní }\end{array}$ & $\begin{array}{c}\text { Etapa } \\
\text { výpočtová }\end{array}$ & \\
\hline \multicolumn{2}{|c|}{$\begin{array}{l}\text { Rovina gnoseologicko- } \\
\text {-metodologická }\end{array}$} & & \multirow{3}{*}{$\begin{array}{l}\text { Konkretizace } \\
\text { jednotlivých } \\
\text { výzkumných } \\
\text { krokủ }\end{array}$} & & & \\
\hline $\begin{array}{l}\text { Rovina } \\
\text { metod }\end{array}$ & $\begin{array}{l}\text { nkrétně } \\
\text { ogická }\end{array}$ & & & & & \\
\hline \multicolumn{2}{|c|}{$\begin{array}{c}\text { Rovina organizačně } \\
\text { technická }\end{array}$} & $\downarrow$ & & & . & \\
\hline
\end{tabular}

univerzální recept na provedení empirického šetření. Opět připomínáme, že vazby mezi jednotlivými elementy nevyjadřují pouze momenty časové, a tedy jen mechanické návaznosti, ale jsou založeny na hluboké a pochopitelně především věcné logice.

Předpoklad, že proces empirického sociologického výzkumu představuje složitě strukturovaný celistvý systém by zůstal značně banální, kdyby nebylo zdůrazněno, že jde o proces dynamický. Ani $\mathrm{v}$ tomto směru není sice zapotřebí prŕliš velké-invence, aby tato teze mohla být dokumentována, přece však tento krok znamená další přiblížení $\mathrm{k}$ specifice sociologického výzkumu. Jde o to, že vazby v uvažovaném systému mají dynamický charakter. Bylo by ovšem zavádějící vidět v empirickém výzkumu ryzí př́ílad již klasické „,zpětné vazby“ - tyto momenty jsou v něm přítomny, leč nelze si představit, že realizace konkrétně metodologických kroků může zpětně ovlivňovat jejich východiska. Viděno konkrétněji, neúspěšnost určitého operacionalizačního postupu nás vede $\mathrm{k}$ hledání lepších východisek, nikdy však nesmí dojít $\mathrm{k}$ situaci, $\mathrm{kdy}$ aplikace určité metody, procedury či techniky určuje předmět a cíl zkoumání.

$\mathrm{Z}$ hlediska výzkumníkova se dynamické aspekty výzkumu projevují v tom, že rozhodnutí v jedné fázi podstatně modifikuje další průběh výzkumu, že současně ve způsobu řešení úkolu existují obvykle různé alternativy postupů (různé co do kvality výsledků, ale i nároků na výzkum). Je tedy nucen ve značné míře předem anticipovat důsledky svých rozhodnutí; bylo by proto možné hovořit o jakési „vstřícné zpětné vazbě“. Další důvod pro dynamické pojetí výzkumu vidíme $\mathrm{v}$ tom, že $\mathrm{v}$ praxi jsme svědky zkracování výzkumu, vypouštění některých etap (např. předvýzkumu), redukce některých kroků. Je-li řádně zdůvodněno (např. zmenšením časových a finančních nároků tam, kde je operaciona- 
lizace vskutku rutinní a ověřenou záležitostí), je každé zkrácení výzkumu př́nosem. Jde jenom o to, aby řetězce vertikálních a horizontálních vazeb mezi jednotlivými kroky nebyly narušeny.

Dynamický charakter empirického sociologického výzkumu souvisí těsně s další jeho podstatnou charakteristikou. Znakem vědecké metody je cílevědomost, směřování k předem vytčenému cíli. Proto i empirický výzkum charakterizují cílesměrné procesy, kdy nám samozřejmě záleží na tom, aby tyto procesy byly cílevědomě řízeny. Cílem empirického výzkumu je vždy shromáždit relevantní empirickou informaci, je ovšem třeba počítat s tím, že její kvalita (rozuměj: rozsah, komplexnost, hloubka, explanační potenciál, atd.) může být různá. $\mathrm{K}$ otázce výzkumných cílů je třeba přistupovat diferencovaně. Přitom je nutno respektovat jejich vazbu na řešený problém, ale i na způsoby řešení dílčích metodologických kroků (zejména v oblasti analýzy předmětu a objektu výzkumu, tvorby hypotéz, ale i při určení výběrového souboru apod.). Některými těmito specifickými vztahy jsme se již zabývali podrobněji. ${ }^{13}$ ) $\mathrm{V}$ duchu předchozích úvah jenom zdůrazňujeme, že dosažení určitého cíle je spojeno nejenom s metodologickými, ale také organizačními stránkami výzkumu. Cíl i jednotlivé prostředky jsou ve vzájemném vztahu a je nutné dosáhnout jejich souladu, dominantní role ovšem připadá i v tom to případě cílům.

I když jsme na počátku zdůraznili, že nelze pojímat sociologický výzkum jako laboratorní, izolovaný proces, zatím jsme náš pohled orientovali spíše dovnitř. Je proto na čase prohlásit, že empirický výzkum považujeme na otevřený systém.

Otevřenost systému výzkumu není dána jen tím, že do něj vstupuje sociální problém, že je vyvoláván potřebami praxe. Předchozí analýza ukázala, že do něj vstupuje - a to ne jednou - teorie a že řešení každého konkrétně metodologického problému vyžaduje přihlédnout $\mathrm{k}$ obecným metodologickým východiskům. Výzkum je otevřen i dalším vlivům, odráží se v něm i ḱnkrétní historická situace, interferují zde motivy a zájmy badatele. Ze strany zadavatele nejde jenom o předložení určité objednávky a zadání výzkumu, jeho názory a požadavky vstupují do procesu $\mathrm{v}$ průběhu oponentních řízení, konzultací apod. $\mathbf{K}$ úspěšné realizaci výzkumu je někdy účelné provést řadu konzultací mimo rámec vlastního výzkumu (odborníci z přibuzných společenskovědních disciplín, statistici, programátoři, operátoři počítače atd.). Stejně tak výstupem z výzkumného procesu není jenom závěrečná zpráva, ale také materiálové studie, projekty, průběžné informace. Všechny tyto vazby na prostředí mají aspekty informační i materiálově energetické (viz např. zajištění tisku dotazníků, rozmnožení závěrečné zprávy apod.).

${ }^{13}$ ) Vedle uvedeného učebního textu viz též J. Buriánek: K souvislosti mezi hypotézami a cílem výzkumu. Sociologický časopis, č. 4, 1981. 
Skutečnost, že empirický sociologický výzkum je otevřeným systémem, přirozeně násobí dynamiku v něm probíhajících procesů a zvyšuje také nároky na jeho řízení. Dosáhnout vytčeného cíle znamená tedy nejenom zvládnout stovku rozhodovacích kroků, ale udržet potřebnou míru kontroly všech vnějších vlivů a optimalizovat podmínky, za kterých výzkum probíhá. $V$ praxi jsme nejednou svědky toho, že se tyto podmínky v průběhu výzkumu mění (at' jde o nároky zadavatele, nebo o změny ve složení výzkumného týmu). Nedomníváme se však - jak by se mohlo zdát na základě výčtu všech komplikací -, že je nutno podléhat pesimismu ve vztahu k realizaci empirického sociologického výzkumu. Předpokladem praktického zvládnutí těchto problémů je ovšem jejich teoretická znalost a ničím nenahraditelná zkušenost $\mathrm{z}$ praktického provádění výzkumu.

$\mathrm{Z}$ hlediska systémového př́stupu jsme se pokusili dokázat, že empirický sociologický výzkum je otevřený, celistvý, vnitřně strukturovaný, dynamický a cílově orientovaný systém. Protože nás zajímají praktické důsledky těchto charakteristik, musíme obrátit pozornost k problematice řízení takového systému.

\section{STRATEGIE EMPIRICKÉHO SOCIOLOGICKEHO VÝZKUMU}

Zatímco se pojmu strategie téměř všeobecně (nejvýrazněji pochopitelně v oblasti vojenství) užívá pro vyjádření dlouhodobého a perspektivního záměru určité aktivity včetně způsobů jeho efektivního dosahování, v sociologickém výzkumu registrujeme spíše tendenci vyhradit tento pojem pouze pro zajištění nezbytných organizačních předpokladů výzkumu. Pokud je vůbec otázce strategie věnována pozornost, pak většinou právě v tomto zúženém pojetí, kdy strategii „tvoří“ volba spolupracovníků a sestavení výzkumného týmu, spojené s rozvržením postupu výzkumu do časového sledu jednotlivých kroků. ${ }^{14}$ ) Cílem je tu jenom jakási „ekonomická optimalizace“, založená na bilanci konečného efektu a nutných nákladů. Tyto otázky, jak jsme již ostatně ukázali, k výzkumu neodlučně patří Naším ideálem však není představa, že po vymezení cílů a celé metodiky výzkumu stačí do projektu ,zakalkulovat" stanovení pracovního týmu, harmonogramu a rozpočtu, a strategie je hotova.

V pojmu strategie empirického sociologického výzkumu musí kondenzovat představa, že celá soustava rozhodovacích procesů musí směřovat $\mathrm{k}$ jedinému cíli, že je třeba zajistit jednotu všech složek empirického výzkumu. V našem

\footnotetext{
${ }^{14}$ ) Jeden z mála př́íkladů je obsažen $v$ Z. Pergler a kol.: Vybrané techniky sociologického výzkumu. Praha, Svoboda 1969.
} 
pojetí strategie, které lze označit jako širší, vyjadřujeme úsilí o harmonizaci teoretickometodologických východisek výzkumu, jeho cílů a zároveň také materiálních a organizačních podmínek.

Do okruhu strategických otázek patři například to, zda lze spoléhat na výše uvedené vnitřní vazby mezi jednotlivými kroky (a na výskyt seberegulujících mechanismů v procesu výzkumu - viz např. otázka pilotáže), zda lze zůstat u pouhého kormidlování mezi úskalími empirického zkoumání $v$. jednotlivých rozhodovacích krocích. Zastáváme názor, že strategie výzkumného úkolu musí ovlivnit celou koncepci práce výzkumníka i řešení těch nejelementárnějších otázek. Týká se to i jeho vztahu k zadavateli výzkumu, i když zde nelze podcènit i prvky t a k t i k y. S tím bude pravděpodobně souhlasit každý, kdo prošel ohněm několika oponentních řízení.

Přesvědčení o významu strategie ovšem samo o sobě nic neřeší. Účinná strategie výzkumné akce musí především respektovat všechny charakteristiky empirického sociologického výzkumu, musí vycházet ze znalosti logiky jeho uspořádání a vazeb mezi jednotlivými kroky. Musí jasně stanovit cíle výzkumu i cestu, po které $\mathrm{k}$ nim bude výzkum směřovat. Přitom je třeba předem odhadnout možné komplikace nebo alternativy řešení. $V$ neposlední řadě pak $k$ dobré strategii patří reálný plán materiálních a organizačních předpokladů. Součástí těchto organizačních předpokladů je i zabezpečení vysoké úrovně řídicí činnosti. Do tohoto okruhu problémů patří i dodržování některých specifických strategických zásad řízení výzkumného procesu.

Pokusíme se nyní právě cestou rozpracování určitých principů strategie výzkumu do podoby zásad ( $v$ tomto směru se nutně dotkneme i některých otázek etiky výzkumné práce) dopracovat názor, že provádění empirických výzkumů není a nemůže být čistě poznávací činností a neslouží $\mathrm{k}$ demonstrování brilance metodologických prostředků. Na základě vlastní zkušenosti z několika výzkumných akcí, které potvrdily známou zkušenost, že realizace empirického výzkumu je záležitostí společensko-praktickou, soustředíme se na některé dosud nedoceněné problémy. Jak už snad ani nemůže být jinak, tvoří níže vyjmenované strategické zásady, uvedené samozřejmě bez nároku na hierarchizaci a úplnost, obligátní „,desatero“:

1. Přizpůsobovat organizační stránku výzkumného problému a cíli:

2. Neodkládat strategická rozhodnutí.

3. Racionálně využívat ekonomii času.

4. Ǩešit úkol v rozmezí vstup - výstup.

5. Adekvátně využívat kolektivních forem prâce.

6. Kontrolovat vstupy.

7. Kontrolovat výstupy.

8. Archivovat materiály. 
9. Umět nést odpovědnost za výzkum.

10. Připravovat půdu pro realizaci výsledků výzkumu.

Tyto zásady ovšem vy̌žadují stručný komentář, a to zejména $\mathrm{z}$ toho hlediska, jakých nedostatků se vlastně máme vyvarovat.

Pruní zásada zdůrazn̆uje základní princip veškeré výzkumné činnosti, přričemž jako protipól vidíme situace, kdy výzkumnou problematiku určují pracovníci, které je třeba żaměstnat, anebo (u aplikovaných výzkumů) dosud nevyčerpané finanční prostředky. Tlakům, kdy otázka předmětu výzkumu a mnohdy vůbec smyslu celé akce je $z$ těchto důvodů (někdy bona fide, ve snaze vyjít výzkumníkům vstříc) posunuta na druhé místo, je třeba rozhodně čelit.

Realizace principu druhého je zatížena určitým rozporem: sami většinou zdůrazňujeme, že př́pravná fáze výzkumu musí být dostatečně dlouhá, především však obsažná. Přesto již na samém počátku žádáme, aby výzkumník jasně stanovil cíle výzkumu i způsoby jejich realizace. Podle našeho názoru je lepší koncepci výzkumu třeba $\mathrm{v}$ dalších fázích opravit, než zahajovat výzkum bez koncepce. Sociolog musí kvalifikovaně vybrat vhodnou strategii a bez zbytečné váhavosti a $\mathrm{s}$ důrazem ji sledovat.

Třetí zásadu lze jednoduše vyložit jako umění zkracovat výzkum. Je strategicky výhodné provést maximum smysluplných redukcí, ne všechny kroky, které do výzkumu patří, je třeba realizovat (pilotáž, předvýzkum, expertní dotazování atd.), u jiných jde o podstatné zkrácení potřebné doby k vyřešení.

Řešit úkol v rozmezí vstup - výstup znamená usilovat o to, aby výzkumník řešil daný úkol od začátku do konce. Není nejšt’astnější vstupovat do již rozběhnutého výzkumu (přebírat řešení apod.), není př́liš morální opouštět výzkum, který jsme započali. Jde o otázky profesionální etiky, většinou se porušování této zásady projeví i na kvalitě celého výzkumu.

Souhlasíme $s$ názorem, že výběr spolupracovníků těsně souvisí se strategií výzkumu. $\mathrm{V}$ naší zásadě chceme vyjádřit několik věcí: nutnost a výhodnost týmové práce, nezbytnost určité dělby práce, problematiku adekvátních forem ř́zení pracovního kolektivu. Z negativních skutečností, které do strategie občas pronikají, jmenujme tendenci ke specializaci. Zatímco je celkem výhodné mít v týmu specialistu-statistika, značně problematická je situace, jakmile dělba práce vyústí ve specializaci „na metody“, „na počítač“, „,na teorii“", „na interpretaci" atd. Stačí, aby vzájemná komunikace jen trochu poklesla, a výzkum se mění $\mathrm{v}$ nepř́lišs sourodou mozaiku individuálních prríspěvků. Představa, že jeden výzkumník realizuje vše od začátku do konce (včetně přepisu závěrečné zpráyy), rychle zastarává. $O$ to aktuálnější jsou otázky sestavování výzkumných týmů, skloubení procesů specializace a kooperace. Svoji úlohu v oblasti strategie výzkumného úkolu musí pochopitelně sehrát predevším vedoucí týmu. Problémů není prosto ani členění týmu na. výkonné pracovníky a konzultanty. 
Kontrola vstupů v našem pojetí postihuje situace, kdy dynamika procesu výzkumu stoupá nad únosnou míru díky neustálému „přísunu“ nových informací, námětů a požadavků. Je snad zřejmé, že nejsme zastánci rigidního pojetí výzkumu, že předem počítáme s tím, že vedle zadání výzkumu a třeba posudku oponentů úvodního projektu vstoupí do výzkumu další informace zvenčí (a to nejen jako produkt předem plánovaných konzultací, např. s programátory). Pokud se objeví zcela nový námět na způsob řešení, pak ho lze přijmout jen tehdy, jestliže výrazným způsobem překonává stávající strategickou linii. V dílčích otázkách ovšem je možno připustit - z důvodů taktických - určité kompromisy. Nám např́klad jeden zadavatel vnutil v pokročilém stadiu řešení úkolu provedení ankety, která byla předem odsouzena $\mathrm{k}$ neúspěchu.

Kontrola výstupů má dva aspekty: ten první představuje názory veřejnosti na kvalitu a efektivitu výzkumu, druhý je specifičtější a týká se prověření všech materiálů, které „půjdou ven“. Není to jenom závěrečná zpráva, ale také úvodní a pracovní projekt či materiálová studie (jako meziprodukt a výsledek konkretizační etapy výzkumu). $V$ této prověrce přisuzujeme rozhodující roli oponentnímu řízení, i když podle našeho soudu není nutné ke každé maličkosti svolávat autoritativní odborné plénum. Náročné a objektivní posouzení výstupů, doprovázené snahou zkvalitnit průběh řešení úkolu, vytváŕí rozhodně príiznivější předpoklady pro hodnocení výzkumu ze strany odborné i laické veřejnosti.

Nejenom pro potreby oponentního ř́zení je vhodné archivovat dokumentaci z výzkumu. Jak zásadní strategická rozhodnutí, tak i běžná agenda v oblasti materiálního a organizačního zabezpečení mají být $v$ průběhu i po skončení výzkumu $\mathrm{k}$ dispozici. Zkušenosti praví, že někdy je podceňována i otázka archivace dat získaných výzkumem.

Smysl deváté zásady je třeba vidět v posouzení významu výzkumu, v odpovědném přistupu $\mathrm{k}$ řešení otázky vztahu cílů a prostř̌edků. Výzkumník rozhoduje o řešitelnosti úkolu, současně je povinen vybrat optimální a nikoli nejpohodlnější řešení, a konečně odpovědět na otázku, zda je schopen na základě svých znalostí a zkušeností výzkum strategicky (a pak $\mathrm{v}$ oblasti operativního řízení) zvládnout. Není možné v tomto ohledu stanovit nějaký předpis, spíše jen varovat před extrémy alibistického, nebo naopak voluntaristického přístupu.

Zásadu desátou jsme formulovali na základě mínění, že o výsledku výzkumu rozhoduje také podstatné okolí systému, především schopnost zadavatele přijímat výsledky. Tento problém se tedy netýká všech empirických výzkumů, určitá kultivace postojů veřejnosti $\mathrm{k}$ možnostem empirických sociologických výzkumů by však měla být společnou záležitostí. Bylo by přehnané žádat, aby každý zadavatel byl předem proškolen a seznámen s tím, co může a co nemá očekávat. Sociolog by však tyto otázky měl začlenit do strategie řešení, nebot' 
mu musí záležet nejenom na tom aby vízzkum na určité úrovni dokončil, ale aby výsledky padly na živnou, a ne na nepřátelsky naladěnou, přezíravou nebo přehnaně optimistickou, různými předsudky zatíženou půdu. Nebudeme asi zadavatele školit, budeme ho však prriměřeně informovat a postupně připravovat na akceptaci (třeba i nepř́ijemných) výsledků.

Snad bylo dostatečně naznačeno, že strategii nechápeme jako návod k porážce nebo k oklamání jakéhosi „protivníka“. Jde nám o to, aby výsledky výzkumné činnosti užitečně sloužily v praxi. Význam strategických otázek výzkumu nelze měřit jenom výši hmotných prostředků, jež jsou výzkumíkům svěřovány. Kořeny strategie empirického výzkumu leží hlouběji než ve sféře ekonomické, spojují metodologické a organizační stránky s etickými otázkami výzkumné činnosti. Hodnotové aspekty řízení výrazným způsobem prostupují celým systémem empirického výzkumu.

\section{ZÁVĚR}

V kontextu úvah o specifických rysech empirického sociologického výzkumu $\mathrm{z}$ hlediska metodologického i $\mathrm{z}$ hlediska předmětu jsme navrhli vymezení empirického sociologického výzkumu jako cílevědomého, systematického a organizovaného získávání informací o (empiricky) konkrétních sociálních jevech a procesech, které jsou zkoumány specificky sociologickými výzkumnými postupy ve vztazích $\mathrm{k}$ jiným sociálním jevům a procesům. Tím jsme zdůraznili, že výzkum nutně musí vycházet $\mathrm{z}$ teorie a že přistupuje ke sběru primární individuální empirické informace s intencí odhalit totalitu vztahů. Při argumentaci ve prospěch adjektiva empirický jsme důsledně využili Marxových úvah o metodě politické ekonomie ${ }^{15}$ ) a prokázali, že výzkum musí směrovat $\mathrm{k}$ „duchovní reprodukci totality“ (a nikoli k „chaotické představě celku“) ve smyslu dosažení teoreticky konkrétního poznání. ${ }^{16}$ )

Naše nynější analýza ukázala, že vedle přítomnosti předmětné teorie i metodologických principů je zárukou systematického empirického zkoumání sociálních jevů i dodržování určitých zásad v samotném pojetí empirického výzkumu. Žádná definice pravděpodobně není s to komplexně vyjádřit všechny důležité aspekty empirického zkoumání. Proto navrhujeme alternativní vymezení, k teré rovněž zahrnuje několik velmi podstatných charakteristik. Empirický sociologický výzkum je složitý, dynamický a organizovaný systém obecně metodologických principů i speciálních identifikačních, indikačních a transformačních

15) Srovnej K. Marx: Rukopisy Grundrisse I. Praha, Svoboda 1971, s. 54 an.

${ }^{16)}$ Podrobněji viz citovaný učební text. 
postupů, cílově orientovaných na získávání sociologických faktů a na nich založené sociální informace sloužící při řešení relevantních sociálních problémů. Jeho strategii chápeme jako uvědomělé komplexní (celostné) řízení tohoto procesu.

Ne všechny prvky uvedeného pojetí empirického sociologického výzkumu jsme v naší studii mohli podrobněji zdůvodnit. Jak jsme naznačili již v úvodu, pozitivní řešení relativně speciální otázky systémového charakteru empirického výzkumu chápeme jako tvorbu přeđipokladů pro zvýšení efektivnosti našeho zkoumání. Věnovali jsme pozornost těm to méně často frekventovaným tématům proto, že velmi úzce souvisejí s problematikou p r a k t i ck é realizace empirického výzkumu, s otázkami řízení. Odstraňování subjektivních překážek ${ }^{17}$ ) $\mathrm{v}$ řídicích procesech, které vytvářejí často zbytečné bariéry vůči procesům poznávacím, považujeme za úkol aktuální, a to nejen v rámci empirického výzkumu, ale celé marxistické sociologie.

\section{LITERATURA}

A f a n a j ev, V. G.: Sociální informace a ř́zení společnosti. Praha 1978.

B l a u be rg, I. V., Ju d i n, E. G . : Stanovlenije i suščnost' sistěmnogo podchoda. Moskva 1973.

Dialektika a systémový př́stup. Praha, Svoboda 1979.

J a d ov, V. A .: Sociologický výskum. Bratislava 1977.

J u d i n, E. G . : Sistěmnyj pochod i princip dějatělnosti. Moskva 1978.'

Marx, K . : Rukopisy „Grundrisse“ I. Praha 1971.

Př́ručka pro sociology. Praha 1980.

S a dovskij, V. N .: Metodologické problémy výzkumu objektů, které tvoří systémy. In: Sociologie v SSSR. Praha 1967.

Z i c h, F.: Sociologický výzkum. Praha 1976.

\section{К ВОПРОСУ СКСТЕМНОЙ КОНЦЕПЦИИ ЭМПИРИЧЕСКИХ СОЦИОЛОГИЧЕСКИХ ИССЛЕДОВАНИЙ}

Pe 3 rom e

Размышления о применении системного подхода в рамках марксистской социологии не могут ограничиваться только решением основных онтологических и методологических вопросов. Идея системного характера познания расп ространяется и на эмпирические социологические исследования. Они понимаются как сложная динамическая и организованная система общих методологических принципов и специальных идентификационных, индикационных и трансформационных методов, ориентированных на получение социологических фактов и основанной на них социальной

$\left.{ }^{17}\right)$ Ctenár̆ jistě pochopí, že jde o překážky plynoucí z malé znalosti zdrojů a principů fungování heuristických postupů. 
информации, служащей для решения релевантных социальных проблем. Освещается значение отдельных мыслей системного подхода, категории общего, среды, элемента, структуры, динамики, целового характера, саморегулирования, управления и т. д. В модели змпирических исследований, наряду с выдвижением часовой оси, рассматриваются и другие размеры, различаюшие отдельные шаги при принятии решения в зависимости от того, насколько общий характер имеют решаемые вопросы.

На основе анализа системных характеристик эмпирических социологических исследований разработана концепция стратегии исследований как комплексного решения всех процессов и, следовательно, не только вопросов материального и организационного обеспечения исследований Подчеркивается влияние цели исследований на методологическо-теоретическую сторону. Формулируются лринципы стратегии и дискутируются проблемы, связаные с их практической реализацией. При зтом указывается и на этические и аксиологические взаимосвязи исследовательской деятельности. Широкая концепция стратегии исследований руководствуется стремлением повысить эффективность процесса эмпирического изучения социальных явлений и процессов.

\section{ZUR SYSTEMAUFFASSUNG DER EMPIRISCHEN SOZIOLOGISCHEN FORSCHUNG}

\section{Z us a m m en assung}

Die Erwägungen über die Anwendung des Systemherangehens an die Wirklichkeit im Rahmen der marxistischen Soziologie können nicht nur auf die Lösung von grundlegenden ontologischen und methodologischen Fragen beschränkt werden. Die Idee des Systemcharakters des wissenschaftlichen Erkennens ist auch auf die empirische soziologische Forschung erweitert. Dieselbe wird als ein kompliziertes dynamisches und organisiertes System von allgemein methodologisches Prinzipien und speziellen Identifikations-, Indikations- und Transformationsmethoden aufgefaßt, auf die Gewinnung soziologischer Fakten und der darauf begründeten sozialen Informationen abgezeielt, die zur Lösung relevanter sozialer Probleme dienen. Es wird die Bedeutung einzelner Ideen vom System - Ansatz, Kategorien als Ganze, Milieu, Element, Struktur, Dynamik, Gezieltheit, Selbsttregulierung, Leitung usw. erläutert. Im Modell der empirischen Forschung wird neben dem Entwurf der Zeitachse eine weitere Dimension erwogen, die einzelne Entscheidungsschritte je nach Maß der Allgemeinheit der zu lösenden.Fragen unterschiedet. Diskutiert wird hier die Frage der Ein- und Ausgänge sowie der inneren Verbundenheiten.

Aufgrund der Analyse der Systemcharakteristiken der empirischen soziologischen Forschung wird die Auffassung der Strategie der Forschung als einer komplexen Leitung aller Prozesse ausgearbeitet, also nicht nur der Fragen der materiellen und Organisationssicherstellung der Forschung. Es wird der Einfluß des Ziels der Wirkung auf die theoretisch-methodologischen und Organisationsseite betont. Es werden da Prinzipien der Strategie formuliert und Probleme diskutiert, die mit deren praktischer Realisation zusammenhängen. Dabei wird auch auf ethische und axiologische Zusammenhänge der Forschungstätigkeit hingewiesen. Die weite Auffassung der Forschungsstrategie wird von den Bestrebungen geleitet, die Effektivität des Prozesses der empirischen Erfoschung sozialer Erscheinungen und Prozesse zu erhöhen. 